\title{
Plant Cysteine Oxidases are Dioxygenases that Directly Enable Arginyl Transferase-Catalyzed Arginylation of N-End Rule Targets
}

\author{
Mark D. White ${ }^{1}$, Maria Klecker ${ }^{2,3}$, Richard J. Hopkinson ${ }^{1}$, Daan Weits ${ }^{4}$, Carolin Mueller ${ }^{5,6}$, \\ Christin Naumann ${ }^{2,3}$, Rebecca O'Neill ${ }^{1}$, James Wickens ${ }^{1}$, Jiayu Yang ${ }^{1}$, Jonathan C. Brooks- \\ Bartlett ${ }^{7}$, Elspeth F. Garman ${ }^{7}$, Tom N. Grossmann ${ }^{5,6}$, Nico Dissmeyer ${ }^{2,3, *}$, Emily Flashman ${ }^{1, *}$ \\ ${ }^{1}$ Chemistry Research Laboratory, University of Oxford, 12 Mansfield Road, Oxford, OX1 \\ 3TA, United Kingdom \\ ${ }^{2}$ Independent Junior Research Group on Protein Recognition and Degradation, Leibniz \\ Institute of Plant Biochemistry (IPB), Weinberg 3, D-06120 Halle (Saale), Germany \\ ${ }^{3}$ ScienceCampus Halle - Plant-based Bioeconomy, Betty-Heimann-Str. 3, D-06120 Halle \\ (Saale), Germany \\ ${ }^{4}$ Institute of Biology I, RWTH Aachen University, Worringerweg 1, D-52074 Aachen, \\ Germany \\ ${ }^{5}$ Chemical Genomics Centre of the Max Planck Society, Department of Chemistry and \\ Chemical Biology, Technische Universität Dortmund, Otto-Hahn-Str. 15, D-44227 \\ Dortmund, Germany \\ ${ }^{6}$ VU University Amsterdam, De Boelelaan 1083, 1081 HV Amsterdam, The Netherlands \\ ${ }^{7}$ Department of Biochemistry, University of Oxford, South Parks Road, Oxford, OX1 3QU, \\ United Kingdom
}

* Corresponding authors: emily.flashman@chem.ox.ac.uk, +44(0)1865 275920

\section{Keywords}

nico.dissmeyer@ipb-halle.de, ++49 (0) 34555821710

cysteine dioxygenase; ethylene response factors; plant hypoxia; N-end rule pathway; arginyl transferase; E3 ubiquitin ligase; proteostasis

\begin{abstract}
Abbreviations
PCO, plant cysteine oxidase; ATE, arginyl tRNA transferase; ERF-VII, group VII ETHYLENE RESPONSE FACTOR; 2OG, 2-oxoglutarate; NMR, nuclear magnetic resonance; Met, methionine; NME, N-terminal Met excision; Nt, N-terminal; NO, nitric oxide; HIF, hypoxia-inducible factor; PHD, prolyl hydroxylase; MALDI-MS, matrixassisted laser desorption/ionization-mass spectrometry; LC-MS, liquid chromatography-mass spectrometry; HRE, HYPOXIA RESPONSIVE ERF; RAP, RELATED TO APETALA2; EBP, ETHYLENE RESPONSE FACTOR 72; CDO, cysteine dioxygenase; MAP, Metaminopeptidase.
\end{abstract}


Abstract

47

Crop yield loss due to flooding is a threat to food security. Submergence-induced hypoxia in plants results in stabilisation of group VII ETHYLENE RESPONSE FACTORS (ERF-VIIs), which aid survival under these adverse conditions. ERF-VII stability is controlled by the $\mathrm{N}$-end rule pathway, which proposes that ERF-VII Nterminal cysteine oxidation in normoxia enables arginylation followed by proteasomal degradation. The PLANT CYSTEINE OXIDASEs (PCOs) have been identified as catalysts of this oxidation. ERF-VII stabilisation in hypoxia presumably arises from reduced PCO activity. We directly demonstrate that PCO dioxygenase activity produces Cys-sulfinic acid at the N-terminus of an ERF-VII peptide, which then undergoes efficient arginylation by an arginyl transferase (ATE1). This is the first molecular evidence showing $\mathbf{N}$-terminal Cys-sulfinic acid formation and arginylation by $\mathrm{N}$-end rule pathway components, and the first ATE1 substrate in plants. The PCOs and ATE1 may be viable intervention targets to stabilise $\mathrm{N}$-end rule substrates, including ERFVIIs to enhance submergence tolerance in agronomy. 
White $M$ et al.

\section{Introduction}

All aerobic organisms require homeostatic mechanisms to ensure $\mathrm{O}_{2}$ supply and demand are balanced. When supply is reduced (hypoxia), a hypoxic response is required to decrease demand and/or improve supply. In animals, this well characterized response is mediated by the Hypoxia-Inducible transcription Factor (HIF), which upregulates genes encoding for vascular endothelial growth factor, erythropoietin and glycolytic enzymes amongst many others. $^{1-3}$ Hypoxia in plants is typically a consequence of reduced $\mathrm{O}_{2}$ diffusion under conditions of waterlogging or submergence, or inside of organs such as seeds, embryos, or floral meristems in buds where the various external cell layers act as diffusion barriers. Although plants can survive temporary periods of hypoxia, flooding negatively impacts on plant growth, and if sustained it can result in plant damage or death ${ }^{4}$. This has a major impact on crop yield; for example, flooding resulted in crop loss costing \$3 billion in the U.S. in $2011 .^{5}$ As climate change results in increased severe weather events including flooding ${ }^{4}$, strategies to address crop survival under hypoxic stress are needed to meet the needs of a growing worldwide population.

The response to hypoxia in rice, Arabidopsis, and barley is known to be mediated by the group VII ETHYLENE RESPONSE FACTORs (ERF-VIIs). ${ }^{6-11}$ It has been found that these transcription factors promote the expression of core hypoxia-responsive genes, including those encoding alcohol dehydrogenase and pyruvate decarboxylase that facilitate anaerobic metabolism. ${ }^{12,13}$ Crucially, it was shown, initially in Arabidopsis, that the stability of the ERF-VIIs is regulated in an $\mathrm{O}_{2}$-dependent manner via the $\mathrm{Arg} / \mathrm{Cys}$ branch of the $\mathrm{N}$-end rule pathway, which directs proteins for proteasomal degradation depending on the identity of their N-terminal amino acid. ${ }^{14-16}$ Thus, a connection between $\mathrm{O}_{2}$ availability and the plant 
White $M$ et al.

87 hypoxic response was identified. ${ }^{11,17,18}$ The Arabidopsis ERF-VIIs are translated with the conserved N-terminal motif MCGGAI/VSDY $/ \mathrm{F}^{4}$ and co-translational N-terminal methionine excision, catalyzed by Met amino peptidases (MAPs) ${ }^{19,20}$, leaves an exposed N-terminal Cys which is susceptible to oxidation. ${ }^{14-16} \mathrm{~N}$-terminally oxidized Cys residues (Cys-sulfinic acid or Cys-sulfonic acid, Supplementary Figure 1) are then proposed to render the ERF-VII Ntermini substrates for arginyl tRNA transferase (ATE)-catalyzed arginylation. The subsequent Nt-Arg-ERF-VIIs are candidates for ubiquitination by the E3 ligase PROTEOLYSIS6 $\left(\right.$ PRT6) $^{21}$ which promotes targeted degradation via the $26 \mathrm{~S}$ proteasome. It has also been shown that degradation of ERF-VIIs by the N-end rule pathway can be influenced by NO, and that the ERF-VIIs play a role in plant NO-mediated stress responses. ${ }^{22,23}$

The plant hypoxic response mimics the equivalent well-characterized regulatory system in animals, whereby adaptation to hypoxia is mediated by HIF. In normoxic conditions, HIF is hydroxylated at specific prolyl residues targeting it for binding to the von Hippel-Lindau tumour suppressor protein ( $\mathrm{pVHL}$ ), the recognition component of the E3-ubiquitin ligase complex, which results in HIF ubiquitination and proteasomal degradation. ${ }^{1,3}$ Thus, while not substrates for the N-end rule pathway of protein degradation, HIF levels are regulated by post-translational modification resulting in ubiquitination, in a manner that is sensitive to hypoxia. HIF prolyl hydroxylation is catalyzed by $\mathrm{O}_{2}$-dependent enzymes, the HIF prolyl hydroxylases (PHDs 1-3), ${ }^{2}$ which are highly sensitive to $\mathrm{O}_{2}$ availability. ${ }^{24,25}$ These $\mathrm{O}_{2}$-sensing enzymes are thus the direct link between $\mathrm{O}_{2}$ availability and the hypoxic response. ${ }^{26,27}$

Crucially, a family of five enzymes, the PLANT CYSTEINE OXIDASEs (PCO1-5) were identified in Arabidopsis ${ }^{28}$ that were reported to catalyze the $\mathrm{O}_{2}$-dependent reaction in the plant hypoxic response, specifically the oxidation of the conserved Cys residue at the N- 
bioRxiv preprint doi: https://doi.org/10.1101/069336; this version posted December 9, 2016. The copyright holder for this preprint (which was not certified by peer review) is the author/funder, who has granted bioRxiv a license to display the preprint in perpetuity. It is made available under aCC-BY-NC 4.0 International license.

White $M$ et al.

terminus of the Arabidopsis ERF-VIIs, RAP2.2, RAP2.12, RAP2.3, HRE1 and HRE2. It was found that overexpression of PCO1 and 2 in planta specifically led to depleted RAP2.12 protein levels and reduced submergence tolerance, while pco1 pco2 T-DNA insertion mutants accumulated RAP2.12 protein. Isolated recombinant PCO1 and PCO2 were shown to consume $\mathrm{O}_{2}$ in the presence of pentameric peptides CGGAI corresponding to the N-termini of various ERF-VIIs (Supplementary Table $\mathbf{1}^{\mathbf{2 8}}$ ). The identification of these enzymes indicates that the hypoxic response in plants is enzymatically regulated, ${ }^{28}$ potentially in a similar manner to the regulation of the hypoxic response in animals by the HIF hydroxylases. The PCOs may therefore act as plant $\mathrm{O}_{2}$ sensors.

Validation of the chemical steps in the Arg/Cys branch of the N-end rule pathway is still limited, both in animals and plants. We therefore sought to provide molecular evidence that the PCOs catalyze the oxidation step in ERF-VII proteasomal targeting and to determine if this step is required for further molecular priming by arginylation. Using mass spectrometry and NMR techniques we confirm that PCO1 and also PCO4 - representatives of the 2 different PCO 'subclasses' based on sequence identity and expression behavior ${ }^{28}$ - catalyze dioxygenation of the N-terminal Cys of Arabidopsis ERF-VII peptide sequences to Cyssulfinic acid $\left(\mathrm{CysO}_{2}\right)$. This oxidation directly incorporates molecular $\mathrm{O}_{2}$. To our knowledge, these are the first described enzymes that catalyze cysteinyl oxidation, as well as being the first described cysteine dioxygenases in plants. We then verify that the Cys-sulfinic acid product of the PCO-catalyzed reactions is a direct substrate for the arginyl tRNA transferase ATE1, demonstrating that PCO activity is relevant and sufficient for the subsequent step of molecular recognition and modification according to the $\mathrm{N}$-end rule pathway. This provides the first molecular evidence that Nt-Cys-sulfinic acid is a bona fide substrate for N-end rule mediated arginylation. Overall, we thus define the PCOs as plant cysteinyl dioxygenases and 
bioRxiv preprint doi: https://doi.org/10.1101/069336; this version posted December 9, 2016. The copyright holder for this preprint (which was not certified by peer review) is the author/funder, who has granted bioRxiv a license to display the preprint in perpetuity. It is made available under aCC-BY-NC 4.0 International license.

White $M$ et al.

137

138

ATE1 as an active arginyl transferase, establishing for the first time a direct link between molecular $\mathrm{O}_{2}$, PCO catalysis and ATE1 recognition and modification of $\mathrm{N}$-end rule substrates.

\section{Results}

\section{PCOs catalyze modification of RAP2 2 -11 in an $\mathrm{O}_{2}$-dependent manner}

N-terminally hexahistidine-tagged recombinant PCO1 and 4 were purified to $\sim 90 \%$ purity, as judged by SDS-PAGE (Supplementary Figure 2a). Protein identity was confirmed by comparison of observed and predicted mass by LC-MS (PCO1 predicted mass 36,510 Da, observed mass 36,513 Da; PCO4 predicted mass 30,680 Da, observed mass 30,681 Da, Supplementary Figure 2b). Both PCO1 and PCO4 were found to be monomeric in solution and to co-purify with substoichiometric levels of $\mathrm{Fe}(\mathrm{II})$ ( $\sim 0.3$ atoms $\mathrm{Fe}$ (II) per monomer, Supplementary Figure 2c-e), in line with the reported parameters of recombinant forms of their distant homologs, the cysteine dioxygenases (CDOs). ${ }^{28-30}$ The activity of the purified PCO1 and PCO4 was tested towards a synthetic 10-mer peptide corresponding to the methionine excised N-termini of the ERF-VIIs RAP2.2, RAP2.12, and HRE2 $\left(\mathrm{H}_{2} \mathrm{~N}-\right.$ CGGAIISDFI-COOH, hereafter termed RAP2 $2-11$ Supplementary Table 1). Assays comprising $\mathrm{RAP}_{2-11}$ at $100 \mu \mathrm{M}$ in the presence or absence of PCO1 or PCO4 at $0.5 \mu \mathrm{M}$ underwent aerobic or anaerobic coincubation for 30 minutes at $30^{\circ} \mathrm{C}$ prior to analysis of the peptide by matrix-assisted laser desorption/ionization-mass spectrometry (MALDI-MS, Figure 1a,b;). Only under aerobic conditions and in the presence of PCO1 or PCO4, did the spectra reveal the appearance of two species with mass increases of $+32 \mathrm{Da}$ and $+48 \mathrm{Da}$, corresponding to two or three added $\mathrm{O}$ atoms, suggesting an $\mathrm{O}_{2}$-dependent reaction for $\mathrm{PCOs}$ 
1 and 4 (Figure 1b), as previously shown for PCOs 1 and 2 (note that supplementation of conducted in this study). ${ }^{28}$ These mass shifts were deemed to be consistent with enzymatic formation of Cys-sulfinic $\left(\mathrm{CysO}_{2},+32\right.$ $\mathrm{Da})$ and Cys-sulfonic acid $\left(\mathrm{CysO}_{3},+48 \mathrm{Da}\right.$;

Supplementary Figure 1). Although homology between the PCOs and CDOs ${ }^{28,30}$ leads to the predisposition that they will perform similar chemistry (i.e. catalyse Cys sulfinic acid formation), both Cys-sulfinic and Cys-sulfonic acid are proposed to be Arg transferase substrates in the $\mathrm{Arg} / \mathrm{Cys}$ branch of $\mathrm{N}$-end rule mediated protein degradation and therefore both were considered as potential products of the PCO-catalysed reaction. ${ }^{14-16}$

\section{PCOs are dioxygenases catalyzing the incorporation of both atoms of $\mathrm{O}_{2}$ into RAP2 2 -11}

To ascertain whether the PCOs function as dioxygenases and thus to confirm a direct connection between molecular $\mathrm{O}_{2}$ and PCO activity, we sought to verify the source of the $\mathrm{O}$ atoms in the oxidized RAP2 $2-11$ by conducting assays in the presence of ${ }^{18} \mathrm{O}_{2}$ as the cosubstrate or $\mathrm{H}_{2}{ }^{18} \mathrm{O}$ as the solvent. To probe $\mathrm{O}_{2}$ as the source of $\mathrm{O}$ atoms in the product, anaerobic solutions of RAP $2_{2-11}$ were prepared in sealed vials before addition of PCO4 using a gas-tight syringe. The vials were then purged with ${ }^{16} \mathrm{O}_{2}$ or ${ }^{18} \mathrm{O}_{2}$ and the reactions were allowed to proceed at $30^{\circ} \mathrm{C}$ for a subsequent 20 minutes. Upon analysis by MALDI-MS, the mass of the products revealed that molecular $\mathrm{O}_{2}$ was incorporated into the Cys-sulfinic acid product (Figure 2a). The Cys-sulfinic acid product had a mass of $+32 \mathrm{Da}$ in the presence of ${ }^{16} \mathrm{O}_{2}$ and +36 Da in the presence of ${ }^{18} \mathrm{O}_{2}$, demonstrating addition of two ${ }^{18} \mathrm{O}$ atoms and indicating that $\mathrm{O}_{2}$ is the source of $\mathrm{O}$ atoms in this product. The Cys-sulfonic acid product had a mass of $+52 \mathrm{Da}$ in the presence of ${ }^{18} \mathrm{O}_{2}$, indicating a third ${ }^{18} \mathrm{O}$ atom had not been incorporated into this product. To probe whether the source of the additional mass in the apparent Cys-sulfonic acid product was an $\mathrm{O}$ atom derived from water, an equivalent reaction 
White $M$ et al.

187

was carried out under aerobic conditions in the presence of $\mathrm{H}_{2}{ }^{18} \mathrm{O}\left(\mathrm{H}_{2}{ }^{18} \mathrm{O}: \mathrm{H}_{2} \mathrm{O}\right.$ in a $3: 1$ ratio).

No additional mass was observed in the peak corresponding to the Cys-sulfonic acid, raising the possibility that the $+48 \mathrm{Da}$ species observed by MALDI-MS is not enzymatically formed. Importantly, following incubation in the presence of $\mathrm{H}_{2}{ }^{18} \mathrm{O}$ no additional mass was observed in the peak corresponding to Cys-sulfinic acid, confirming that this species is a product of a reaction where molecular $\mathrm{O}_{2}$ is a substrate (Figure $\mathbf{2 b}$ ).

To further investigate whether the PCO-catalyzed product species observed at $+48 \mathrm{Da}$ is enzymatically produced or an artefact of the MALDI-MS analysis method, we turned to liquid chromatography-mass spectrometry (LC-MS) to analyze the products of the PCOcatalyzed reactions. Under these conditions, only peptidic product with a mass increase of +32 Da was observed after incubation with both PCO1 and PCO4, corresponding to the incorporation of two $\mathrm{O}$ atoms and the formation of Cys-sulfinic acid (Figure 2c), consistent with the products observed using ${ }^{18} \mathrm{O}_{2}$ and $\mathrm{H}_{2}{ }^{18} \mathrm{O}$ (Figure 2a,b). No product was observed with a mass corresponding to Cys-sulfonic acid, which suggested that the +48 Da product detected by MALDI-MS was indeed an artefact. When combined with the observation that significant quantities of Cys-sulfonic acid were not seen in no-enzyme or in anaerobic controls (Figure 1), it was hypothesized that the Cys-sulfinic acid product of the PCOcatalyzed reaction is non-enzymatically converted to Cys-sulfonic acid during MALDI-MS analysis, potentially as a result of laser exposure. Upon subjecting the products of PCO1 and 4 turnover to MALDI-MS analysis with increasing laser intensity, a direct correlation between laser intensity and the ratio of Cys-sulfonic acid:Cys-sulfinic acid product was observed (Supplementary Figure 3a). Of note, significant levels of laser induced formation of +32 and +48 Da species upon analysis of unmodified peptide were not observed (Supplementary Figure 3b). Together, these results confirm that the $+48 \mathrm{Da}$ species 
bioRxiv preprint doi: https://doi.org/10.1101/069336; this version posted December 9, 2016. The copyright holder for this preprint (which was not certified by peer review) is the author/funder, who has granted bioRxiv a license to display the preprint in perpetuity. It is made available under aCC-BY-NC 4.0 International license.

White $M$ et al.

observed following incubation of the PCOs with RAP2 $2-11$ are a product of Cys-sulfinic acid exposure to the MALDI-MS laser, and not a product of the PCO-catalyzed reaction. Overall, these data demonstrate that the PCOs are dioxygenase enzymes, similar to the mammalian and bacterial cysteine dioxygenases (CDOs) to which they show sequence homology. ${ }^{28,30}$

\section{PCOs catalyze oxidation of N-terminal Cys of RAP2 2 -11 to form Cys-sulfinic acid}

Recombinant $\mathrm{PCO} 1$ and $\mathrm{PCO} 2$ were reported to consume $\mathrm{O}_{2}$ in the presence of pentameric CGGAI peptides corresponding to the methionine-excised N-terminus of the Arabidopsis ERF-VIIs. ${ }^{28}$ To definitively verify that the N-terminal cysteinyl residue of RAP2 2 -11 is indeed the target for the PCO-catalyzed +32 Da modifications, we conducted LC-MS/MS analyses on the reaction products. Fragmentation of RAP $2_{2-11}$ that had been incubated in the presence and absence of PCO1 and PCO4 revealed b- and y-ion series consistent with oxidation of the N-terminal Cys residue (Figure 3a), confirming that PCOs 1 and 4 act as cysteinyl dioxygenases.

As a final confirmation of the nature of the reaction catalyzed by $\mathrm{PCO} 1$ and $\mathrm{PCO} 4$, their activity was monitored using ${ }^{1} \mathrm{H}-\mathrm{NMR}$. Reactions were initiated by adding $5 \mu \mathrm{M}$ enzyme to $500 \mu \mathrm{M} \mathrm{RAP} 2_{2-11}$ (in the presence of $10 \% \mathrm{D}_{2} \mathrm{O}$ ) and products of the reaction were analysed using a $600 \mathrm{MHz}$ NMR spectrometer. In the presence of both PCO1 and PCO4, modification to the cysteinyl residues was observed, as exemplified by the disappearance of the ${ }^{1} \mathrm{H}$ resonance corresponding to the $\beta$-cysteinyl protons (at $\delta_{\mathrm{H}} 2.88 \mathrm{ppm}$ ) and the emergence of a new ${ }^{1} \mathrm{H}$-resonance at $\delta_{\mathrm{H}} 2.67 \mathrm{ppm}$ (Figure 3b). The chemical shift of the new resonance is similar to that observed for L-Cys conversion to L-Cys-sulfinic acid by mouse CDO, ${ }^{31}$ and also to the chemical shift of an L-Cys-sulfinic acid standard measured under equivalent conditions to the PCO assays (Supplementary Figure 4). Therefore, the resonance shift observed upon PCO1/4 reaction was assigned to the $\beta$-protons of L-Cys-sulfinic acid. Overall 
bioRxiv preprint doi: https://doi.org/10.1101/069336; this version posted December 9, 2016. The copyright holder for this preprint (which was not certified by peer review) is the author/funder, who has granted bioRxiv a license to display the preprint in perpetuity. It is made available under aCC-BY-NC 4.0 International license.

White $M$ et al.

these results provide confirmation at the molecular level that Arabidopsis PCOs 1 and 4 act as plant cysteinyl dioxygenases, catalyzing incorporation of $\mathrm{O}_{2}$ into $\mathrm{N}$-terminal Cys residues on a RAP2 peptide to form Cys-sulfinic acid.

\section{ATE1 arginylates acidic $\mathbf{N}$-termini including Cys-sulfinic acid}

We next sought to confirm that the PCO-catalyzed Cys-oxidation to Cys-sulfinic acid renders a RAP2 peptide capable of and sufficient for onward modification by ATE1. Cys-sulfinic acid has been proposed as a substrate for ATE1 on the basis of its structural homology with known ATE1 substrates Asp and Glu, but evidence has only been reported to date for arginylation of Cys-sulfonic acid. ${ }^{32,33}$ We further sought to validate the role of a plant ATE1: To date ATE1 has been suggested to be responsible for transfer of ${ }^{3} \mathrm{H}$-arginine to bovine $\alpha$ lactalbumin in highly purified plant extracts in vitro ${ }^{34}$ and RAP2.12 stabilization in atel ate 2 double null mutant plant lines implicates ATE1 as an ERF-VII-targeting arginyl transferase in vivo. ${ }^{17,18}$ To this end, we produced recombinant hexahistidine-tagged Arabidopsis ATE1

(Supplementary Figure 5) for use in an arginylation assay which detects incorporation of radiolabeled ${ }^{14} \mathrm{C}$-Arg into biotinylated peptides. C-terminally biotinylated RAP2 $2-13$ peptides $\left(\mathrm{H}_{2} \mathrm{~N}\right.$-XGGAIISDFIPP(PEG)K(biotin)- $\left.\mathrm{NH}_{2}\right)$ where the $\mathrm{N}$-terminal residue, $\mathrm{X}$, constitutes Gly, Asp, Cys or Cys-sulfonic acid were subjected to the arginylation assay in the presence or absence of PCO1/4 (Figure 4a). Peptide with an N-terminal Gly did not accept Arg, while an N-terminal Asp did accept Arg, independent of the presence of PCO1 or 4. A peptide comprising an N-terminal Cys-sulfonic acid was also shown to be a substrate for ATE1, again independent of the presence of PCO1 or 4, which is in line with proposed steps of the Arg/Cys N-end rule pathway and has also recently been reported using a similar assay with mouse ATE1. ${ }^{14-16,35}$ Crucially, in the absence of PCO1/4, RAP2 $2-13$ with an N-terminal Cys 
bioRxiv preprint doi: https://doi.org/10.1101/069336; this version posted December 9, 2016. The copyright holder for this preprint (which was not certified by peer review) is the author/funder, who has granted bioRxiv a license to display the preprint in perpetuity. It is made available under aCC-BY-NC 4.0 International license.

White $M$ et al.

was not an acceptor of arginine transfer by ATE1, yet when either PCO1 or PCO4 was incorporated in the reaction, significant ATE1 transferase activity was observed (Figure 4a).

To confirm that the increased detection of radiolabelled arginine corresponded to arginyl incorporation at the $\mathrm{N}$-termini of the peptides, the experiment was repeated using nonradiolabeled arginine in the presence and absence of PCO4 and ATE1, and peptide products subjected to LC-MS analysis (Figure 4c). As with RAP2 $2-11$ (Figure 2c), the Cys-initiated RAP2 $2-13$ peptide displayed a +32 Da increase in mass upon incubation with PCO4 only (Figure 4c, red spectrum). Importantly, following incubation of Cys-initiated RAP2 $2-13$ with both PCO4 and ATE1, a mass increase equivalent to oxidation coupled to arginylation $(+188$ Da) was observed (Figure 4c, blue spectrum). Subsequent tandem MS analysis of these product ions revealed fragmentation species consistent with the assumption that oxidation and sequential arginylation occur at the N-terminus of PCO4- and ATE1-treated peptides (Figure 4d, blue spectrum), strongly suggesting that the PCO-oxidized N-termini of ERFVIIs are rendered N-degrons via additional arginylation (Figure 4b).

A +12 Da mass increase was observed in products of control assays lacking PCO4 (Figure 4c, $\mathbf{d}$; purple spectra). This appeared to be related to prolonged incubation in the presence of HEPES and DTT as used in the arginylation assay buffer: The +12 Da modification was not observed if the peptide was dissolved in $\mathrm{H}_{2} \mathrm{O}$ (Figure 4c, black spectrum) or if incubated with HEPES and DTT for just 1 hour, but was observed when the peptide was incubated with HEPES and DTT overnight (Supplementary Figure 6). It is proposed that under these conditions, trace levels of contaminating formaldehyde react with free $\mathrm{Nt}-\mathrm{Cys}$ residues to form thiazolidine $\mathrm{N}$-termini. ${ }^{36}$

These results are in line with proposed arginylation requirements for the Arg/Cys branch of the $\mathrm{N}$-end rule pathway ${ }^{14-16}$ including the known Cys-initiated arginylation targets from 
bioRxiv preprint doi: https://doi.org/10.1101/069336; this version posted December 9, 2016. The copyright holder for this preprint (which was not certified by peer review) is the author/funder, who has granted bioRxiv a license to display the preprint in perpetuity. It is made available under aCC-BY-NC 4.0 International license.

White $M$ et al.

mammals. $^{32,33,35,37}$ Importantly, these results demonstrate for the first time Arg transfer mediated by a plant ATE dependent on the N-terminal residue of its substrate, and also that both Cys-sulfinic acid (the product of PCO-catalysis) and Cys-sulfonic acid can act as substrates for ATE1. In particular, the arginylation observed with PCO-catalyzed Cys-sulfinic acid supports the assumption that $\mathrm{N}$-terminal residues sterically and electrostatically resembling Asp or Glu can serve as Arg acceptors in reactions catalyzed by ATEs, ${ }^{33}$ and also confirms the importance of the PCOs as a connection between the stability of their ERF-VII substrates and $\mathrm{O}_{2}$ availability (Figure $4 \mathbf{b}$ ).

\section{Discussion}

The PCOs were identified in Arabidopsis thaliana as a set of five enzymes suggested to catalyze oxidation of N-terminal cysteine residues in ERF-VII transcription factors and oxygen consumption was demonstrated for reactions with short peptides corresponding to their $\mathrm{N}$-termini ${ }^{28}$. This putative oxidation was associated with destabilization of the ERFVIIs, presumably by rendering them substrates of the Arg/Cys branch of the N-end rule pathway. ${ }^{14,16}$ Under conditions of sufficient $\mathrm{O}_{2}$ availability, ERF-VII protein levels are decreased, while under hypoxic conditions, such as those encountered upon plant submergence or in the context of organ development, ERF-VII levels remain high. ${ }^{17,18}$ Importantly, the ERF-VII transcription factors are known to upregulate genes which allow plants to cope with or respond to submergence. ${ }^{13}$ The PCOs are proposed to act as potential $\mathrm{O}_{2}$ sensors involved in regulating the plant hypoxic response. ${ }^{28}$

We sought to biochemically confirm the role of the PCOs in the plant hypoxic response, and present here mass spectrometry and NMR data that clearly demonstrate that two enzymes 
White $M$ et al.

from different 'subclasses' of this family, PCOs 1 and 4, are dioxygenases that catalyze direct incorporation of $\mathrm{O}_{2}$ into RAP2 2 -11 peptides to form Cys-sulfinic acid. Their direct use of $\mathrm{O}_{2}$ supports the proposal that these enzymes may act as plant $\mathrm{O}_{2}$ sensors. ${ }^{28}$ A relationship has been demonstrated between $\mathrm{O}_{2}$ concentration and PCO activity, ${ }^{28}$ but it will be of interest to perform detailed kinetic characterization of these enzymes to ascertain their level of sensitivity to $\mathrm{O}_{2}$ availability, in particular to determine whether their $\mathrm{O}_{2}$-sensitivity is similar to that of the HIF hydroxylases in animals. ${ }^{24,25}$ Although there is functional homology between the PCOs and the HIF hydroxylases, they are apparently mechanistically divergent: The PCOs show sequence homology to the Fe(II)-dependent CDO family of enzymes which do not require an external electron donor for $\mathrm{O}_{2}$ activation, ${ }^{28,30}$ while the HIF hydroxylases are $\mathrm{Fe}(\mathrm{II}) / 2 \mathrm{OG}-d e p e n d e n t$ oxygenases. They also co-purified with $\mathrm{Fe}(\mathrm{II})$ as reported for both the $\mathrm{CDOs}^{29}$ and PHD2 ${ }^{38}$. Of note, the PCOs are the first identified CDOs in plants. Further, in contrast to the reactions of mammalian and bacterial CDOs which oxidize free L-Cys, the PCOs are also, to our knowledge, the first identified cysteinyl (as opposed to free L-Cys) dioxygenases.

According to the Arg/Cys branch of the N-end rule pathway, N-terminal Cys oxidation is proposed to enable successive arginylation by ATE1 to render proteins as N-degrons. While both Cys-sulfinic and Cys-sulfonic acid are repeatedly reported as potential arginylation substrates $^{14-16}$, detailed evidence has only been presented to date for arginylation of Cyssulfonic acid ${ }^{32,33}$ and this only in a mammalian system. We therefore sought to demonstrate that PCO-catalyzed ERF-VII N-terminal Cys oxidation to Cys-sulfinic acid promotes arginylation by ATE1. The arginylation assay and mass spectrometry results we present demonstrate that the PCO-catalyzed dioxygenation reaction is sufficient to trigger $\mathrm{N}$-terminal arginylation of RAP2s by ATE1, thus likely rendering ERF-VIIs (at least those comprising 
White $M$ et al.

the tested $\mathrm{N}$-terminal sequence) as $\mathrm{N}$-degrons, i.e. recognition by PRT6 and other potential E3 ubiquitin ligases, polyubiquitination and possibly transfer to the $26 \mathrm{~S}$ proteasome for proteolysis. ${ }^{14-16}$ Collectively therefore, we present the comprehensive molecular evidence confirming the Cys-oxidation and subsequent arginylation steps of the Arg/Cys branch of the $\mathrm{N}$-end rule pathway. ${ }^{32,33,37}$ We also confirm that ATE1 is able to selectively arginylate, as predicted, ${ }^{33}$ acidic N-terminal residues of plant substrates, including Cys-sulfonic acid.

Arginylation has been known as a posttranslational modification since $1963,{ }^{39}$ to possess a general aminoacyl transferase function in plants (rice and wheat) since $1973^{40}$ and to have a speculative involvement in the N-end rule pathway since $1988 .{ }^{41,42}$ ATE1 is reported as being capable of arginylating proteins at both acidic N-termini and midchain acidic side chains via canonical and non-canonical peptide bonds, respectively. ${ }^{43}$ Reports of midchain arginylation highlighted a potentially broad involvement of ATEs in posttranslational protein modifications for various functions ${ }^{35,43,44,45}$ but was only very recently brought into question by ${ }^{14} \mathrm{C}$-Arg incorporation assays using arrays of immobilized synthetic peptides. ${ }^{35,43,44}$ To date however only one physiological and two in vitro substrates for the Arg/Cys branch of the $\mathrm{N}$-end rule pathway have been characterized, namely mammalian regulator of $\mathrm{G}$ protein signaling (RGS) 4, and RGS5 and 10 respectively, ${ }^{46}$ where Nt-Cys oxidation was described (to Cys-sulfonic acid) as was Nt-Cys arginylation. ${ }^{33,37}$ The first non Cys-branch N-end rule arginylation target was shown to require posttranslational proteolytic cleavage of a (pre-)proprotein. The C-terminal fragment of proteolytically cleaved mouse BRCA1 is Aspinitiated $^{47}$ and gets degraded in an $\mathrm{N}$-end rule-dependent manner. Then, the molecular chaperone BiP (GRP78 and HSPA5, heat shock $70 \mathrm{kDa}$ protein 5) and the oxidoreductase protein disulphide isomerase (PDI), present Glu or Asp after cleavage of their signal peptide, respectively, and were suggested but not shown as putative $\mathrm{N}$-end rule substrates $(\mathrm{Hu}$ et al. 
JBC, 2006). Only very recently, BiP and PDI were identified in mammalian cell culture together with the Glu-initiated calreticulin (CRT) as arginylation targets with a function in autophagy rather than the N-end rule degradation. ${ }^{48}$

Similarly, data regarding the molecular requirements of plant ATEs are limited. Already in 1973, a general aminoacyl transfer activity was found in rice and wheat cell extracts, however, the nature of enzyme, acceptor position and mechanism remained unclear. It was suggested that the N-terminus could serve as Arg acceptor. ${ }^{40}$

The first description of a mutant of the single translatable ATE1 gene in the Arabidopsis accession Wassilewskija (Ws-0) highlighted a role of ATEs in plant development. Ws-0 lacks the second bona fide ATE, that is ATE2, due to a single nucleotide polymorphism in ATE2 causing a premature stop. ${ }^{49}$ Developmental functions of the single homolog ATE1 in the moss Physcomitrella patens were recently described. ${ }^{50}$ Interaction partners of the enzyme were found as well as four arginylated peptides immunologically detected by using antibodies directed against peptides mimicking N-terminal Arg-Asp or Arg-Glu. ${ }^{51}$ In one case, that is the acylamino-acid-releasing enzyme PpAARE, which presents for unknown reasons a neoN-terminal Asp residue which was formerly Asp2 and therefore initiated by Met, an Nterminal arginylation was found with high confidence.Previously, Arg transferase function of Arabidopsis ATE1/2 has been shown using an assay detecting conjugation of ${ }^{3} \mathrm{H}$-Arg to bovine $\alpha$-lactalbumin (bearing an N-terminal Glu) in the presence of plant extracts from wild type Arabidopsis, and atel and ate 2 single mutants but not from ate 1 ate 2 double mutant seedlings. ${ }^{34}$ Therefore, the results we present here demonstrate for the first time Arg transferase activity of a plant ATE towards known plant N-end rule substrates. 
Interestingly, in combination with $\mathrm{O}_{2}$, nitric oxide was identified as an RGS oxidizing agent, suggesting a potential role of S-nitrosylation in the Arg/Cys branch of the $\mathrm{N}$-end rule pathway, albeit non-enzymatically controlled. ${ }^{32}$ It has also been reported in planta that both $\mathrm{NO}$ and $\mathrm{O}_{2}$ are required for ERF-VII degradation, potentially at the Cys oxidation step. ${ }^{22,23}$ Although in N-end rule-mediated RGS4/5 degradation it has been proposed that Cysnitrosylation precedes Cys-oxidation (also currently considered a non-enzymatic process), we find that under the conditions used, the PCO1/4-catalyzed reaction does not require either prior cys-nitrosylation or exogenous NO to proceed efficiently. We cannot rule out that NO plays a role in formation of a Cys-sulfonic acid product, which is also a substrate for ATE1 as shown in our Arg transfer experiments. Alternatively, NO may have a role in ERF-VII degradation in vivo via non-enzymatic oxidation or via a secondary mechanism. The manner in which $\mathrm{NO}$ contributes to $\mathrm{Arg} / \mathrm{Cys}$ branch of the N-end rule pathway therefore remains to be elucidated.

ERF-VII stabilization has been shown to result in improved submergence tolerance, elegantly demonstrated in barley by mutation of the candidate E3-ubiquitin ligase $P R T 6,{ }^{11}$ but also in rice containing the $S u b 1 A$ gene; SUB1A is an apparently stable ERF-VII that confers particular flood tolerance in certain rare varieties of rice. ${ }^{9,17}$ Overexpression of SublA in more commonly grown rice varieties has resulted in a $45 \%$ increase in yield relative to subla mutant lines after exposure to flooding. ${ }^{52}$ If ERF-VII stabilization is indeed a proficient mechanism for enhancing flood tolerance, then manipulation of PCO or ATE activity may be an efficient and effective point of intervention. This work presents molecular validation of their function, providing the basis for future targeted chemical/genetic inhibition of their activity. It also highlights genetic strategies for breeding via introgression of variants of Nend rule pathway components or introduction of alleles of enzymatic components of the N- 
bioRxiv preprint doi: https://doi.org/10.1101/069336; this version posted December 9, 2016. The copyright holder for this preprint (which was not certified by peer review) is the author/funder, who has granted bioRxiv a license to display the preprint in perpetuity. It is made available under aCC-BY-NC 4.0 International license.

White $M$ et al.

408 end rule pathway from non-crop species into crops. . Any of these strategies has the potential

409 to result in stabilized ERF-VII levels and therefore increase stress resistance and may

410 therefore help to address food security challenges. 
White $M$ et al.

Online Methods

412

\section{Peptide Synthesis, Purification and Characterization}

All reagents used were purchased from Sigma-Aldrich unless otherwise stated. The 10-mer

RAP2 2 -11 peptide $\left(\mathrm{H}_{2} \mathrm{~N}-\mathrm{CGGAIISDFI-COOH}\right)$ was purchased from GL Biochem (Shanghai)

Ltd, China (Supplementary Table 1). The sequence of the 12-mer peptides used in the coupled oxidation-arginylation assay is derived from RAP2.2 and RAP2.12 $\left(\mathrm{H}_{2} \mathrm{~N}-\mathrm{X}-\right.$

GGAIISDFIPP(PEG)K(biotin)- $\mathrm{NH}_{2}$ ) and synthesized by Fmoc-based solid-phase peptide synthesis (SPPS) on NovaSyn ${ }^{\circledR}$ TGR resin (Merck KGaA, Supplementary Table 2). Fmoc protected amino acids (Iris Biotech $\mathrm{GmbH}$ ) were coupled using 4 equivalents of (eq) of the amino acid according to the initial loading of the resin. 4 eq amino acid was mixed with 4 eq O-(6-chlorobenzotriazol-1-yl)-N,N,N',N'-tetramethyluronium hexafluorophosphate (HCTU) and 8 eq N,N-diisopropylethylamine (DIPEA; Santa Cruz Biotechnology, sc-293894) and added to the resin for $1 \mathrm{~h}$. In a second coupling, the resin was treated with 4 eq of the Fmocprotected amino acid mixed with 4 eq benzotriazole-1-yl-oxy-tris-pyrrolidino-phosphonium hexafluoro-phosphate (PyBOP) and 8 eq 4-methylmorpholine (NMM) for $1 \mathrm{~h}$. After double coupling a capping step to block free amines was performed using acetanhydride and DIPEA in N-methyl-2-pyrrolidinone (NMP) (1:1:10) for 5 min. The $C$-terminal Fmoc-Lys(biotin)$\mathrm{OH}$, the 8-(9-fluorenylmethyloxycarbonyl-amino)-3.6-dioxaoctanoic acid (PEG) linker and the different Fmoc protected N-terminal amino acids were coupled manually. The remaining peptide sequence was assembled using an automated synthesizer (Syro II, MultiSynTech $\mathrm{GmbH}$ ). Fmoc deprotection was performed using $20 \%$ piperidine in dimethylformamide 
$2 \mathrm{~h}$, twice. The cleavage solutions were combined and peptides were precipitated with diethyl ether $\left(\mathrm{Et}_{2} \mathrm{O}\right)$ at $-20^{\circ} \mathrm{C}$ for $30 \mathrm{~min}$. Peptides were solved in water/acetonitrile (ACN) 7:3 and purified by reversed-phase high performance liquid chromatography (HPLC; Nucleodur C18 culumn; $10 \times 125 \mathrm{~mm}, 110 \AA, 5 \mu \mathrm{m}$ particle size; Macherey-Nagel) using a flow rate of $6 \mathrm{ml} \cdot \mathrm{min}^{-1}$ (A: ACN with $1 \%$ TFA, B: water with $1 \%$ TFA). Obtained pure fractions were pooled and lyophilized. Peptide characterization was performed by analytical HPLC (1260 Infinity, Agilent Technology; flow rate of $1 \mathrm{ml} \cdot \mathrm{min}^{-1}$, A: ACN with $1 \%$ TFA, B: water with $1 \%$ TFA) coupled with a mass spectrometer (6120 Quadrupole LC/MS, Agilent Technology) using electro spray ionization (Agilent Eclipse XDB-C18 culumn, $4.6 \times 150 \mathrm{~mm}, 5 \mu \mathrm{m}$ particle size). Analytical HPLC chromatograms were recorded at $210 \mathrm{~nm}$ (Supplementary

Figure 7). Quantification was performed by HPLC-based comparison (chromatogram at 210 nm) with a reference peptide (Supplementary Table 2).

\section{Preparation of Recombinant Proteins}

Arabidopsis PCO1 and PCO4 sequences in pDEST17 bacterial expression vectors (Invitrogen) were kindly provided by F. Licausi and J. van Dongen. ${ }^{28}$ Plasmids were transformed into BL21(DE3) Escherichia coli cells, and expression of recombinant protein carrying an N-terminal hexahistidine tag was induced with $0.5 \mathrm{mM}$ IPTG and subsequent growth at $18^{\circ} \mathrm{C}$ for 18 hours. Harvested cells were lysed by sonication and proteins purified using $\mathrm{Ni}^{++}$affinity chromatography, before buffer exchange into $250 \mathrm{mM} \mathrm{NaCl} / 50 \mathrm{mM}$ Tris$\mathrm{HCl}(\mathrm{pH}$ 7.5). Analysis by SDS-PAGE and denaturing liquid-chromatography mass spectrometry (LC-MS) showed proteins with more than $90 \%$ purity and with the predicted molecular weights. 
bioRxiv preprint doi: https://doi.org/10.1101/069336; this version posted December 9, 2016. The copyright holder for this preprint (which was not certified by peer review) is the author/funder, who has granted bioRxiv a license to display the preprint in perpetuity. It is made available under aCC-BY-NC 4.0 International license.

White $M$ et al.

461

462

tobacco etch virus (TEV) recognition sequence for facilitated downstream purification ("tev":

ENLYFQ-X) using the primers ate1_tev_ss GCTTAGAGAATCTTTATTTTCAGGGGATGTCTTTGAAAAACGATGCGAGT-3’) and ate1_as

\section{GGGGACCACTTTGTACAAGAAAGCTGGGTATCAGTTGATTTCATACACCATTCTC}

TC-3'). A second PCR using the primers adapter (5'GGGGACAAGTTTGTACAAAAAAGCAGGCTTAGAGAATCTTTATTTTCAGGGG-3')

and ate1_as was performed to amplify the construct to use it in a BP reaction for cloning into pDONR201 (Invitrogen) followed by an LR reaction into the vector pDEST17 (Invitrogen). The N-terminal hexahistidine fusion was expressed in BL21-CodonPlus (DE3)-RIL Escherichia coli (E. coli) cells. The expression culture was induced with $1 \mathrm{mM}$ IPTG at $\mathrm{OD}=0.6$ and grown for 16 hours at $18^{\circ} \mathrm{C}$. After resuspension in LEW buffer $(50 \mathrm{mM}$ $\mathrm{NaH}_{2} \mathrm{PO}_{4}, \mathrm{pH} 8 ; 300 \mathrm{mM} \mathrm{NaCl} ; 1 \mathrm{mM}$ DTT), the cells were lysed by incubation with 1.2 $\mathrm{mg} / \mathrm{ml}$ lysozyme for $30 \mathrm{~min}$ and underwent subsequent sonification in the presence of $1 \mathrm{mM}$ PMSF. Recombinant protein was purified by $\mathrm{Ni}^{++}$affinity chromatography and subjected to Amicon Ultra-15 (30K) (Merck Millipore) filtration for buffer exchange to imidazole-free LEW containing 20\% glycerol.

\section{PCO Activity Assays and MALDI Analysis}

PCO activity assays were conducted under the following conditions unless otherwise stated: 1 $\mu \mathrm{M}$ PCO1 or 4 was mixed with 100 or $200 \mu \mathrm{M} \mathrm{RAP2} 2_{2-11}$ peptide in $250 \mathrm{mM} \mathrm{NaCl}, 1 \mathrm{mM}$ dithiothreitol (DTT), $50 \mathrm{mM}$ Tris- $\mathrm{HCl} \mathrm{pH} 7.5$ and incubated at $30^{\circ} \mathrm{C}$ for $30-60$ minutes. Addition of exogenous Fe(II) and/or ascorbate were not required for activity. Assays were stopped by quenching $1 \mu \mathrm{L}$ sample with $1 \mu \mathrm{L}$ alpha-cyano-4-hydroxycinnamic acid (CHCA) matrix on a MALDI plate prior to product mass analysis using a Sciex 4800 TOF/TOF mass 
bioRxiv preprint doi: https://doi.org/10.1101/069336; this version posted December 9, 2016. The copyright holder for this preprint (which was not certified by peer review) is the author/funder, who has granted bioRxiv a license to display the preprint in perpetuity. It is made available under aCC-BY-NC 4.0 International license.

White $M$ et al.

spectrometer (Applied Biosystems) operated in negative ion reflectron mode. The instrument parameters and data acquisition were controlled by 4000 Series Explorer software and data processing was completed using Data Explorer (Applied Biosystems).

To test the activity of PCO4 in the presence of ${ }^{18} \mathrm{O}_{2}, 100 \mu \mathrm{L}$ of an anaerobic solution of 100 $\mu \mathrm{M}$ RAP2 $2-11$ in $250 \mathrm{mM} \mathrm{NaCl} / 50 \mathrm{mM}$ Tris- $\mathrm{HCl} \mathrm{pH} 7.5$ was prepared in a septum-sealed glass vial by purging with $100 \% \mathrm{~N}_{2}$ for 10 minutes at $100 \mathrm{~mL} / \mathrm{min}$ using a mass flow controller (Brooks Instruments), as used for previous preparation of anaerobic samples to determine enzyme dependence on $\mathrm{O}_{2} \cdot{ }^{24} \mathrm{PCO} 4$ was then added using a gas-tight Hamilton syringe, followed by purging with a balloon (approx. $0.7 \mathrm{~L}$ ) of ${ }^{16} \mathrm{O}_{2}$ or ${ }^{18} \mathrm{O}_{2}$ over the course of 10 minutes at room temperature. Reaction vials were then transferred to $30^{\circ} \mathrm{C}$ for a further 20 minutes before products were analysed by MALDI-MS as described above.

PCO4 activity was additionally tested in the presence of $\mathrm{H}_{2}{ }^{18} \mathrm{O}$ by conducting an assay in $75 \% \mathrm{H}_{2}{ }^{18} \mathrm{O}, 25 \% \mathrm{H}_{2} \mathrm{O}$ (with all enzyme/substrate/buffer components comprising a portion of the $\mathrm{H}_{2} \mathrm{O}$ fraction). Assays were conducted for 10 minutes at room temperature followed by 20 minutes at $30^{\circ} \mathrm{C}$ for comparison with assays conducted with ${ }^{18} \mathrm{O}_{2}$. Products were analysed by MALDI-MS, as described above.

\section{UPLC-MS and MS/MS Analysis of PCO Assay Products}

Ultra-high performance chromatography (UPLC) mass spectrometry (MS) measurements were obtained using an Acquity UPLC system coupled to a Xevo G2-S Q-ToF mass spectrometer (Waters) operated in positive electrospray mode. Instrument parameters, data acquisition and data processing were controlled by Masslynx 4.1. Source conditions were adjusted to maximize sensitivity and minimize fragmentation while Lockspray was employed 
bioRxiv preprint doi: https://doi.org/10.1101/069336; this version posted December 9, 2016. The copyright holder for this preprint (which was not certified by peer review) is the author/funder, who has granted bioRxiv a license to display the preprint in perpetuity. It is made available under aCC-BY-NC 4.0 International license.

White $M$ et al.

511

512

during analysis to maintain mass accuracy. $2 \mu \mathrm{L}$ of each sample was injected on to a Chromolith Performance RP-18e 100-2 mm column (Merck) heated to $40{ }^{\circ} \mathrm{C}$ and eluted using a gradient of $95 \%$ deionized water supplemented with $0.1 \%(\mathrm{v} / \mathrm{v})$ formic acid (analytical grade) to $95 \%$ acetonitrile (HPLC grade) and a flow rate of $0.3 \mathrm{~mL} / \mathrm{min}$. Fragmentation spectra of substrate and product peptide ions (MS/MS) were obtained using a targeted approach with a typical collision-induced dissociation (CID) energy ramp of 30 to $40 \mathrm{eV}$. Analysis was carried out with the same source settings, flow rate and column elution conditions as above.

\section{${ }^{1}$ H NMR Assay}

Reaction components (5 $\mu \mathrm{M}$ PCO1 or PCO4 and $500 \mu \mathrm{M} \mathrm{RAP2} 2_{2-11}$ ) were prepared to $75 \mu \mathrm{L}$ in $156 \mathrm{mM} \mathrm{NaCl}, 31 \mathrm{mM}$ Tris- $\mathrm{HCl}(\mathrm{pH} 7.5)$ and $10 \% \mathrm{D}_{2} \mathrm{O}$ (enzyme added last), in a $1.5 \mathrm{~mL}$ microcentrifuge tube before being transferred to a $2 \mathrm{~mm}$ diameter NMR tube. ${ }^{1} \mathrm{H}$ NMR spectra at $310 \mathrm{~K}$ were recorded using a Bruker AVIII 600 (with inverse cryoprobe optimized for ${ }^{1} \mathrm{H}$ observation and running topspin 2 software; Bruker) and reported in p.p.m. relative to $\mathrm{D}_{2} \mathrm{O}\left(\delta_{\mathrm{H}}\right.$ 4.72). The deuterium signal was also used as internal lock signal and the solvent signal was suppressed by presaturating its resonance.

\section{Arginylation Assay}

The conditions for arginylation of the 12-mer peptide substrates were modified from ${ }^{43}$. In detail, ATE1 was incubated at $10 \mu \mathrm{M}$ in the reaction mixture containing 50 mM HEPES, $\mathrm{pH}$ 7.5; $25 \mathrm{mM} \mathrm{KCl} ; 15 \mathrm{mM} \mathrm{MgCl}$; 1 mM DTT; $2.5 \mathrm{mM}$ ATP; $0.6 \mathrm{mg} / \mathrm{ml}$ E. coli tRNA (R1753, Sigma); $0.04 \mathrm{mg} / \mathrm{ml}$ E. coli aminoacyl-tRNA synthetase (A3646, Sigma); $80 \mu \mathrm{M}(4 \mathrm{nCi} / \mu \mathrm{l})$

${ }^{14} \mathrm{C}$-arginine (MC1243, Hartmann Analytic); $50 \mu \mathrm{M}$ C-terminally biotinylated 12-mer peptide 
bioRxiv preprint doi: https://doi.org/10.1101/069336; this version posted December 9, 2016. The copyright holder for this preprint (which

was not certified by peer review) is the author/funder, who has granted bioRxiv a license to display the preprint in perpetuity. It is made available under aCC-BY-NC 4.0 International license.

White $M$ et al.

536 substrate and, where indicated, $1 \mu \mathrm{M}$ purified recombinant PCO1 or PCO4 in a total reaction

537 volume of $50 \mu \mathrm{L}$. The reaction was conducted at $30^{\circ} \mathrm{C}$ for 16 to 40 hours. After incubation, 538 each $50 \mu \mathrm{L}$ of avidin agarose bead slurry (20219, Pierce) equilibrated in PBSN (PBS539 Nonidet; $100 \mathrm{mM} \mathrm{NaH} 2 \mathrm{PO}_{4} ; 150 \mathrm{mM} \mathrm{NaCl} ; 0.1 \%$ Nonidet-P40) was added to the samples 540 and mixed with an additional $350 \mu \mathrm{L}$ of PBSN. After 2 hours of rotation at room temperature, 541 the beads were washed 4 times in PBSN, resuspended in $4 \mathrm{~mL}$ of FilterSafe scintillation 542 solution (Zinsser Analytic) and scintillation counting was performed using a Beckmann 543 Coulter LS 6500 Multi-Purpose scintillation counter. 
White $M$ et al.

\section{Acknowledgements}

Petra Majovsky, Domenika Thieme and Wolfgang Hoehenwarter from the Proteomics Unit of the Leibniz Institute of Plant Biochemistry (IPB), Halle, are acknowledged for mass spectrometry of recombinant ATE1. David Staunton from the Biophysical Facility, Department of Biochemistry, University of Oxford is acknowledged for multi-angle light scatter analysis of PCO1/4. Geoff Grime from the University of Surrey Ion Beam Centre is acknowledged for assistance with the microPIXE data collection. This work was supported by a Biotechnology and Biological Sciences Research Council (U.K.) New Investigator grant (BB/M024458/1) to E.F., a grant for setting up the junior research group of the ScienceCampus Halle - Plant-based Bioeconomy to N.D., by a Ph.D. fellowship of the Landesgraduiertenförderung Sachsen-Anhalt awarded to C.N., by an Engineering and Physical Sciences Research Council (U.K.) studentship (EP/G03706X/1) to J.B-B., a Royal Society Dorothy Hodgkin Fellowship to E.F., a William R. Miller Junior Research Fellowship (St. Edmund Hall, Oxford) to R.H. and grant DI 1794/3-1 by the German Research Foundation (Deutsche Forschungsgemeinschaft, DFG) to N.D. Financial support came from the Leibniz Association, the state of Saxony Anhalt, the Deutsche Forschungsgemeinschaft (DFG) Graduate Training Center GRK1026 “Conformational Transitions in Macromolecular Interactions" at Halle, and the Leibniz Institute of Plant Biochemistry (IPB) at Halle, Germany. We thank Prof. J. van Dongen (RWTH Aachen University, Germany) and Prof. F. Licausi (Scuolo Superiore Sant'Anna, Pisa, Italy) for sharing pDEST-PCO plasmids and helpful discussions. 
bioRxiv preprint doi: https://doi.org/10.1101/069336; this version posted December 9, 2016. The copyright holder for this preprint (which

was not certified by peer review) is the author/funder, who has granted bioRxiv a license to display the preprint in perpetuity. It is made available under aCC-BY-NC 4.0 International license.

White $M$ et al.

566

567

568

569

570

571

572

573

574

575

576

577

578

579

580

581

\section{Author Contributions}

M.W. performed the PCO1/4 activity assays and MALDI/LC-/MS/MS analyses. M.K. performed and established arginylation reactions on peptides coupled to biotin pulldown and scintillation measurements and purified ATE1 protein. R.H. performed the NMR assays with E.F. D.W. prepared the pDEST17-PCO1 and 4 plasmids. C.M. synthesized the peptides, T.N.G. supervised and designed the synthesis, C.N. cloned and established purification and activity assays for ATE1. R.O. conducted LC-MS to analyse +12 Da mass shifts. J.W. performed LC-MS analysis. J.Y. and J.C.B-B. prepared samples for micro-PIXE analysis and J.C.B-B. and E.F.G. collected and analysed micro-PIXE data. This work was supported by the network of the European Cooperation in Science and Technology (COST) Action BM1307_ “ European network to integrate research on intracellular proteolysis pathways in health and disease (PROTEOSTASIS). E.F. performed the PCO1 and PCO4 protein purification and selected activity assays. E.F., M.W., M.K. and N.D. designed the study, E.F. and N.D. wrote the manuscript. M.W., M.K., N.D. and E.F. designed the figures. All authors read and approved the final version of this manuscript. 
White $M$ et al.

582

583

584

585

586

587

588

589

590

591

592

593

594

595

596

597

598

599

600

601

602

603

604

605

606

607

608

609

610

611

612

613

614

615

616

617

618

619

620

621

622

623

624

625

626

627

628

629

630

\section{References}

1. Kaelin, W.G., Jr. \& Ratcliffe, P.J. Oxygen sensing by metazoans: the central role of the HIF hydroxylase pathway. Mol Cell 30, 393-402 (2008).

2. Myllyharju, J. Prolyl 4-hydroxylases, master regulators of the hypoxia response. Acta Physiol (Oxf) 208, 148-65 (2013).

3. Semenza, G.L. Oxygen sensing, homeostasis, and disease. N Engl J Med 365, 537-47 (2011).

4. Bailey-Serres, J. et al. Making sense of low oxygen sensing. Trends Plant Sci 17, 129-38 (2012).

5. Bailey-Serres, J., Lee, S.C. \& Brinton, E. Waterproofing crops: effective flooding survival strategies. Plant Physiol 160, 1698-709 (2012).

6. Hattori, Y. et al. The ethylene response factors SNORKEL1 and SNORKEL2 allow rice to adapt to deep water. Nature 460, 1026-U116 (2009).

7. Hinz, M. et al. Arabidopsis RAP2.2: an ethylene response transcription factor that is important for hypoxia survival. Plant Physiol 153, 757-72 (2010).

8. Licausi, F. et al. HRE1 and HRE2, two hypoxia-inducible ethylene response factors, affect anaerobic responses in Arabidopsis thaliana. Plant J 62, 302-15 (2010).

9. $\mathrm{Xu}, \mathrm{K}$. et al. Sub1A is an ethylene-response-factor-like gene that confers submergence tolerance to rice. Nature 442, 705-8 (2006).

10. Papdi, C. et al. Functional identification of Arabidopsis stress regulatory genes using the controlled cDNA overexpression system. Plant Physiol 147, 528-42 (2008).

11. Mendiondo, G.M. et al. Enhanced waterlogging tolerance in barley by manipulation of expression of the N-end rule pathway E3 ligase PROTEOLYSIS6. Plant Biotechnol J 14, 40-50 (2016).

12. Lee, S.C. et al. Molecular characterization of the submergence response of the Arabidopsis thaliana ecotype Columbia. New Phytol 190, 457-71 (2011).

13. Mustroph, A. et al. Profiling translatomes of discrete cell populations resolves altered cellular priorities during hypoxia in Arabidopsis. Proc Natl Acad Sci U S A 106, 18843-8 (2009).

14. Varshavsky, A. The N-end rule pathway and regulation by proteolysis. Protein Sci 20, 12981345 (2011).

15. Tasaki, T., Sriram, S.M., Park, K.S. \& Kwon, Y.T. The N-end rule pathway. Annu Rev Biochem 81, 261-89 (2012).

16. Gibbs, D.J., Bacardit, J., Bachmair, A. \& Holdsworth, M.J. The eukaryotic N-end rule pathway: conserved mechanisms and diverse functions. Trends Cell Biol 24, 603-611 (2014).

17. Gibbs, D.J. et al. Homeostatic response to hypoxia is regulated by the N-end rule pathway in plants. Nature 479, 415-8 (2011).

18. Licausi, F. et al. Oxygen sensing in plants is mediated by an $\mathrm{N}$-end rule pathway for protein destabilization. Nature 479, 419-22 (2011).

19. Ross, S., Giglione, C., Pierre, M., Espagne, C. \& Meinnel, T. Functional and developmental impact of cytosolic protein $\mathrm{N}$-terminal methionine excision in Arabidopsis. Plant Physiol 137, 623-37 (2005).

20. Giglione, C., Boularot, A. \& Meinnel, T. Protein N-terminal methionine excision. Cell Mol Life Sci 61, 1455-74 (2004).

21. Garzon, M. et al. PRT6/At5g02310 encodes an Arabidopsis ubiquitin ligase of the N-end rule pathway with arginine specificity and is not the CER3 locus. FEBS Lett 581, 3189-96 (2007).

22. Gibbs, D.J. et al. Nitric oxide sensing in plants is mediated by proteolytic control of group VII ERF transcription factors. Mol Cell 53, 369-79 (2014).

23. Gibbs, D.J. et al. Group VII Ethylene Response Factors Coordinate Oxygen and Nitric Oxide Signal Transduction and Stress Responses in Plants. Plant Physiol 169, 23-31 (2015). 
White $M$ et al.

24. Tarhonskaya, $\mathrm{H}$. et al. Investigating the contribution of the active site environment to the slow reaction of hypoxia-inducible factor prolyl hydroxylase domain 2 with oxygen. Biochem $J$ (2014).

25. Hirsila, M., Koivunen, P., Gunzler, V., Kivirikko, K.I. \& Myllyharju, J. Characterization of the human prolyl 4-hydroxylases that modify the hypoxia-inducible factor. $J$ Biol Chem 278, 30772-80 (2003).

26. Bruick, R.K. Oxygen sensing in the hypoxic response pathway: regulation of the hypoxiainducible transcription factor. Genes Dev 17, 2614-23 (2003).

27. Epstein, A.C. et al. C. elegans EGL-9 and mammalian homologs define a family of dioxygenases that regulate HIF by prolyl hydroxylation. Cell 107, 43-54 (2001).

28. Weits, D.A. et al. Plant cysteine oxidases control the oxygen-dependent branch of the N-endrule pathway. Nat Commun 5, 3425 (2014).

29. Imsand, E.M., Njeri, C.W. \& Ellis, H.R. Addition of an external electron donor to in vitro assays of cysteine dioxygenase precludes the need for exogenous iron. Arch Biochem Biophys 521, 10-7 (2012).

30. Joseph, C.A. \& Maroney, M.J. Cysteine dioxygenase: structure and mechanism. Chem Commun (Camb), 3338-49 (2007).

31. Li, W. \& Pierce, B.S. Steady-state substrate specificity and O2-coupling efficiency of mouse cysteine dioxygenase. Arch Biochem Biophys 565, 49-56 (2015).

32. Hu, R.G. et al. The N-end rule pathway as a nitric oxide sensor controlling the levels of multiple regulators. Nature 437, 981-6 (2005).

33. Kwon, Y.T. et al. An essential role of N-terminal arginylation in cardiovascular development. Science 297, 96-9 (2002).

34. Graciet, E. et al. The N-end rule pathway controls multiple functions during Arabidopsis shoot and leaf development. Proc Natl Acad Sci U S A 106, 13618-23 (2009).

35. Wadas, B., Piatkov, K.I., Brower, C.S. \& Varshavsky, A. Analyzing N-terminal Arginylation through the Use of Peptide Arrays and Degradation Assays. J Biol Chem 291, 20976-20992 (2016).

36. Kallen, R.G. The mechanism of reactions involving Schiff base intermediates. Thiazolidine formation from L-cysteine and formaldehyde. J Am Chem Soc 93, 6236-48 (1971).

37. Davydov, I.V. \& Varshavsky, A. RGS4 is arginylated and degraded by the N-end rule pathway in vitro. J Biol Chem 275, 22931-41 (2000).

38. McNeill, L.A. et al. Hypoxia-inducible factor prolyl hydroxylase 2 has a high affinity for ferrous iron and 2-oxoglutarate. Mol Biosyst 1, 321-4 (2005).

39. Kaji, H., Novelli, G.D. \& Kaji, A. A Soluble Amino Acid-Incorporating System from Rat Liver. Biochim Biophys Acta 76, 474-7 (1963).

40. Manahan, C.O. \& App, A.A. An arginyl-transfer ribonucleic Acid protein transferase from cereal embryos. Plant Physiol 52, 13-6 (1973).

41. Ciechanover, A. et al. Purification and characterization of arginyl-tRNA-protein transferase from rabbit reticulocytes. Its involvement in post-translational modification and degradation of acidic NH2 termini substrates of the ubiquitin pathway. J Biol Chem 263, 11155-67 (1988).

42. Bohley, P., Kopitz, J. \& Adam, G. Surface hydrophobicity, arginylation and degradation of cytosol proteins from rat hepatocytes. Biol Chem Hoppe Seyler 369 Suppl, 307-10 (1988).

43. Wang, J. et al. Arginyltransferase ATE1 catalyzes midchain arginylation of proteins at side chain carboxylates in vivo. Chem Biol 21, 331-7 (2014).

44. Eriste, E. et al. A novel form of neurotensin post-translationally modified by arginylation. $J$ Biol Chem 280, 35089-97 (2005).

45. Wong, C.C. et al. Global analysis of posttranslational protein arginylation. PLoS Biol 5, e258 (2007).

46. Lee, M.J. et al. RGS4 and RGS5 are in vivo substrates of the N-end rule pathway. Proc Natl Acad Sci U S A 102, 15030-5 (2005). 
bioRxiv preprint doi: https://doi.org/10.1101/069336; this version posted December 9, 2016. The copyright holder for this preprint (which was not certified by peer review) is the author/funder, who has granted bioRxiv a license to display the preprint in perpetuity. It is made available under aCC-BY-NC 4.0 International license.

White M et al.

47. Piatkov, K.I., Brower, C.S. \& Varshavsky, A. The N-end rule pathway counteracts cell death by destroying proapoptotic protein fragments. Proc Natl Acad Sci U S A 109, E1839-47 (2012).

48. Cha-Molstad, $\mathrm{H}$. et al. Amino-terminal arginylation targets endoplasmic reticulum chaperone BiP for autophagy through p62 binding. Nat Cell Biol 17, 917-29 (2015).

49. Yoshida, S., Ito, M., Callis, J., Nishida, I. \& Watanabe, A. A delayed leaf senescence mutant is defective in arginyl-tRNA:protein arginyltransferase, a component of the N-end rule pathway in Arabidopsis. Plant J 32, 129-37 (2002).

50. Schuessele, C. et al. Spatio-temporal patterning of arginyl-tRNA protein transferase (ATE) contributes to gametophytic development in a moss. New Phytol 209, 1014-27 (2016).

51. Hoernstein, S.N. et al. Identification of Targets and Interaction Partners of Arginyl-tRNA Protein Transferase in the Moss Physcomitrella patens. Mol Cell Proteomics 15, 1808-22 (2016).

52. Dar, M.H., de Janvry, A., Emerick, K., Raitzer, D. \& Sadoulet, E. Flood-tolerant rice reduces yield variability and raises expected yield, differentially benefitting socially disadvantaged groups. Sci Rep 3, 3315 (2013). 
bioRxiv preprint doi: https://doi.org/10.1101/069336; this version posted December 9, 2016. The copyright holder for this preprint (which

was not certified by peer review) is the author/funder, who has granted bioRxiv a license to display the preprint in perpetuity. It is made available under aCC-BY-NC 4.0 International license.

White $M$ et al.

697

Figures

698

a

$\mathbf{N}_{2}$

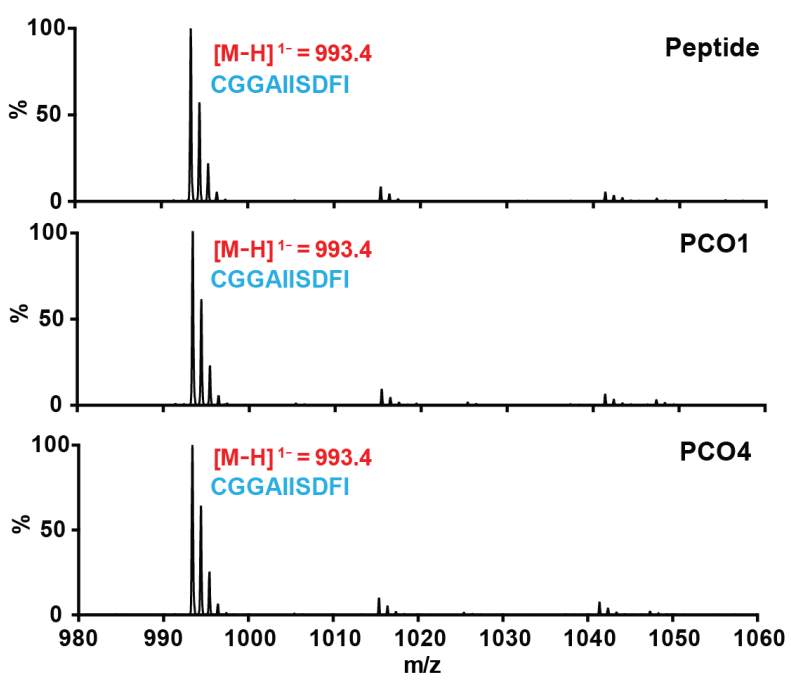

b

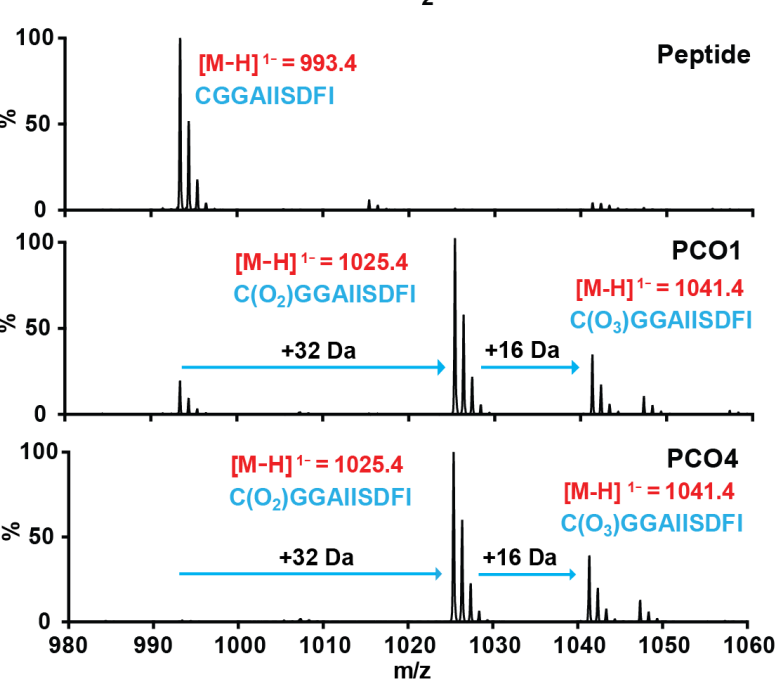

700

701

Figure 1. PCO1, $\mathrm{PCO} 4$ and $\mathrm{O}_{2}$-dependent modification of a $\mathrm{RAP2}_{2-11}$ peptide substrate,

702

consistent with Cys-oxidation. MALDI-MS spectra showing products following PCO1 and

PCO4 incubation with RAP22-11 under anaerobic (a) or aerobic (b) conditions. Products with mass increases of $+32 \mathrm{Da}$ and +48 Da were only observed in the presence of PCO1 or PCO4 and $\mathrm{O}_{2}$. 
White $M$ et al.

a

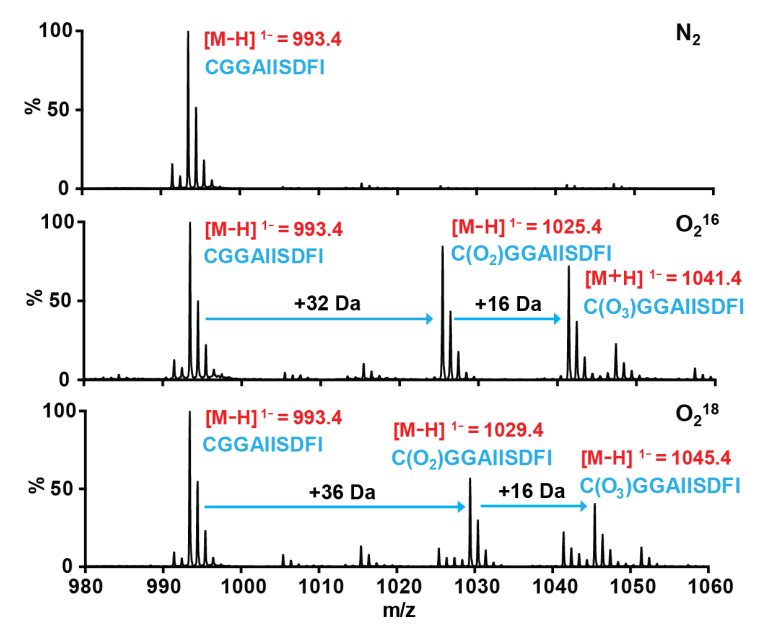

C
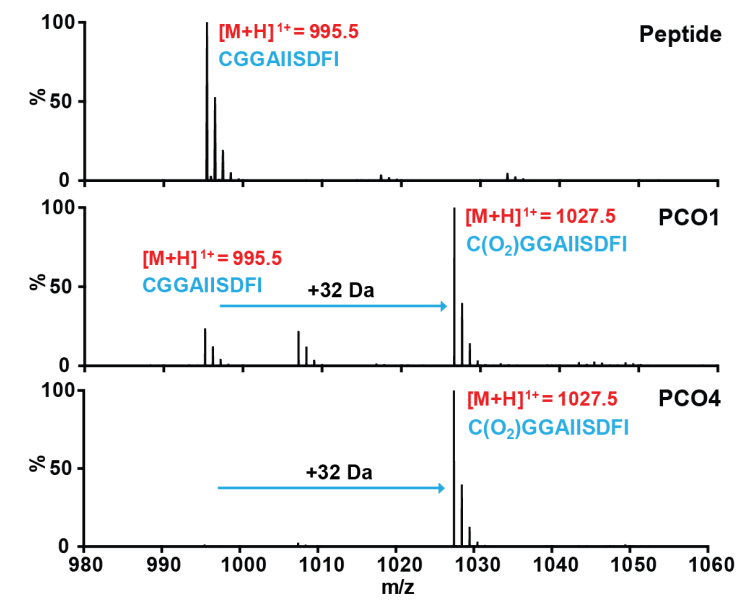
of +32 Da, consistent with Cys-sulfinic acid formation. b

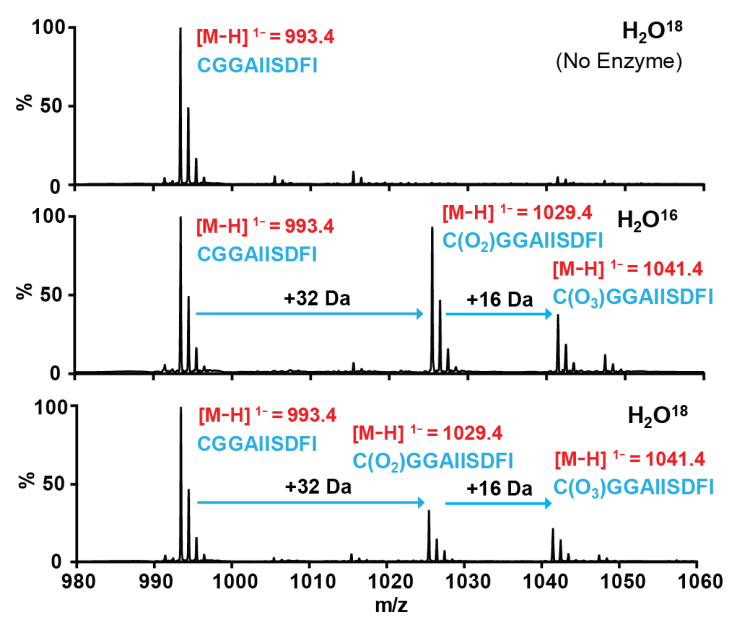

Figure 2. The PCOs are dioxygenases which catalyze incorporation of molecular $\mathrm{O}_{2}$ into

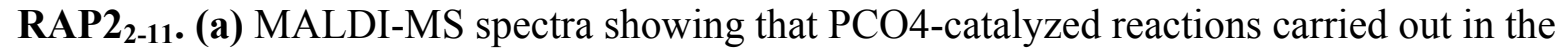
presence of ${ }^{18} \mathrm{O}_{2}$ result in a +4 Da increase in the mass of the putative Cys-sulfinic acid product, however a +6 Da increase in the size of the putative Cys-sulfonic acid product is not observed; (b) MALDI-MS spectra showing that PCO4-catalyzed reactions carried out in the presence of $\mathrm{H}_{2}{ }^{18} \mathrm{O}$ show no additional incorporation of mass compared with products of reactions in the presence of $\mathrm{H}_{2}{ }^{16} \mathrm{O}$; (c) LC-MS spectra confirm that the +48 Da reaction product is an artifact of MALDI-MS analysis (Supplementary Figure 3) and incubation of PCO1 and PCO4 with RAP2 $2-11$ results in formation of a single product with a mass increase 
a
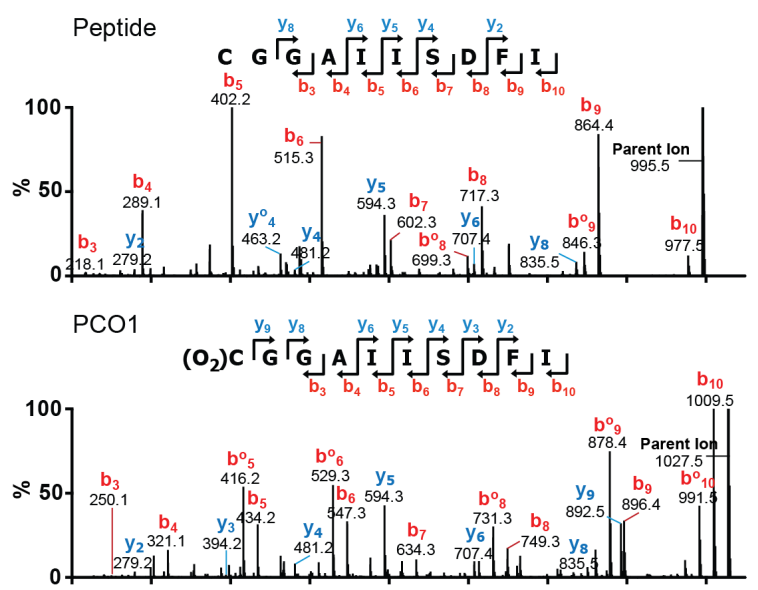

$\mathrm{PCO} 4$

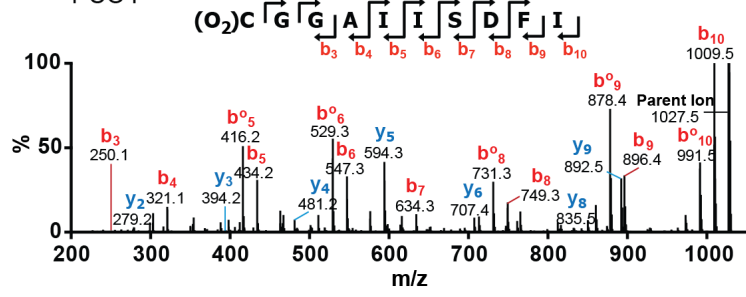

b

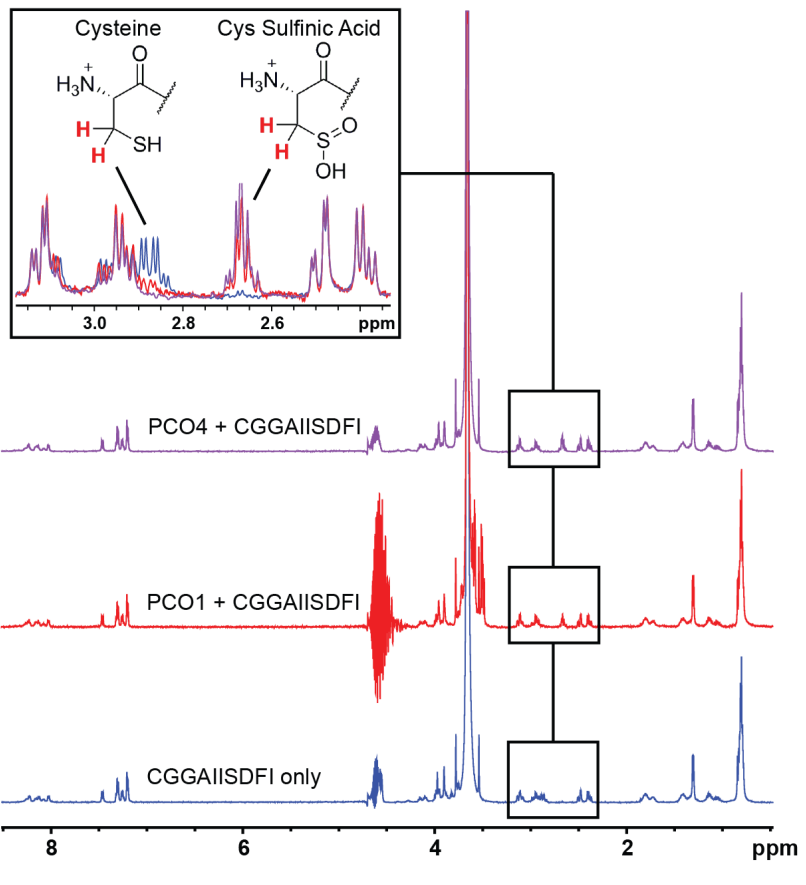

Figure 3. PCO1 and PCO4 oxidize the N-terminal Cys of RAP2 2 -11 to Cys-sulfinic acid

reactions were subjected to LC-MS/MS analysis. In the presence of enzyme, fragment assignment was consistent with expected $b$ - and y-series ion masses for RAP $2_{2-11}$ with Nterminal Cys-sulfinic acid. (b) ${ }^{1} \mathrm{H}-\mathrm{NMR}$ was used to monitor changes to RAP2 $2-11(500 \mu \mathrm{M})$ upon incubation with enzyme $(5 \mu \mathrm{M})$. In the presence of PCO1 (red) and PCO4 (purple), the ${ }^{1} \mathrm{H}$-resonance at $\delta_{\mathrm{H}} 2.88 \mathrm{ppm}$ (assigned to the $\beta$-cysteinyl protons of RAP2 2 -11, blue) was observed to decrease in intensity, with concomitant emergence of a resonance at $\delta_{\mathrm{H}} 2.67 \mathrm{ppm}$. This new resonance was assigned to the $\beta$-protons of Cys-sulfinic based on chemical shift analysis (see Supplementary Figure 4). 
a

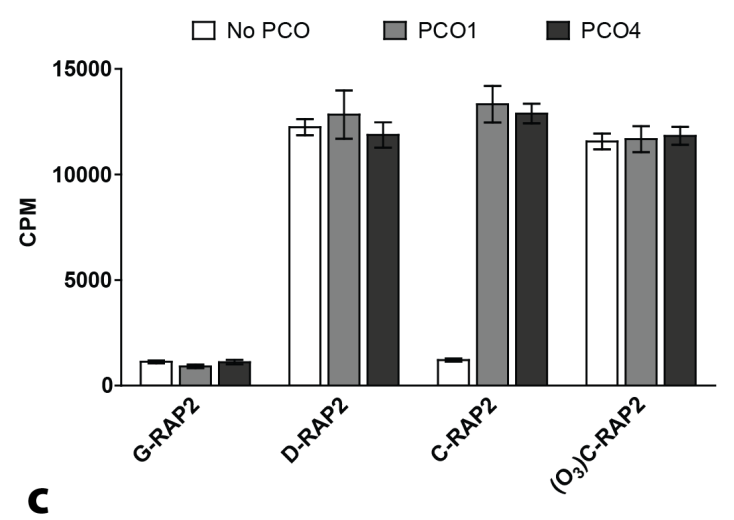

C
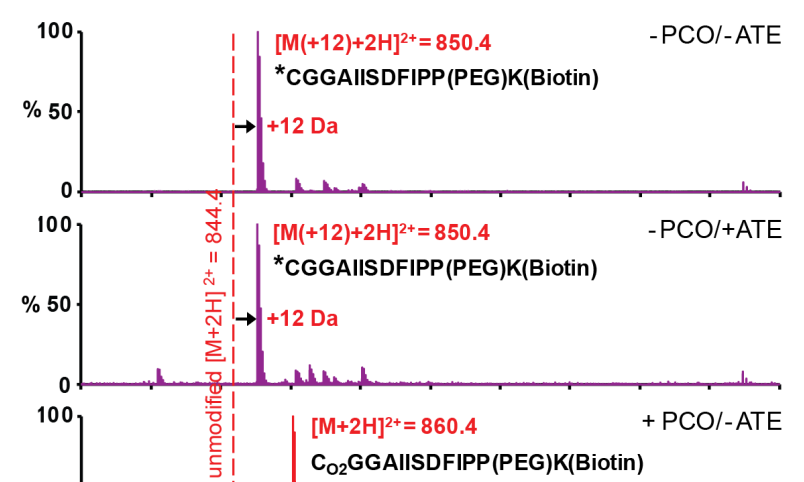
$\mathrm{C}_{\mathrm{O} 2}$ GGAIISDFIPP(PEG)K(Biotin)
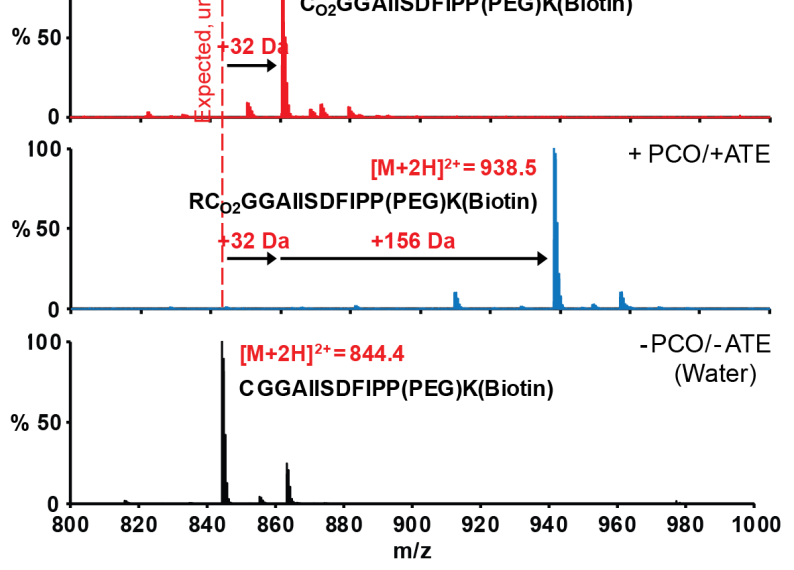

b<smiles>[R120]C(CS(=O)O)CS(=O)NC(=O)[C@H]([NH3+])CCCNC(=N)N</smiles>

d

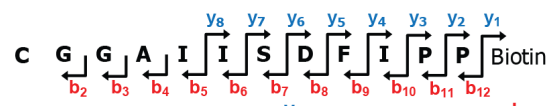

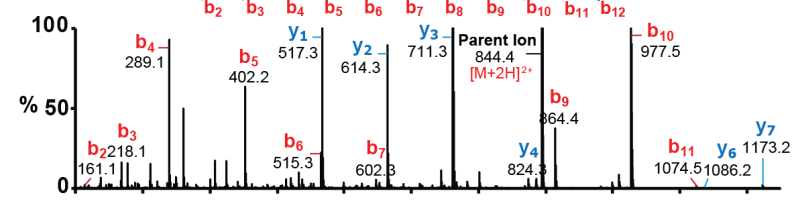

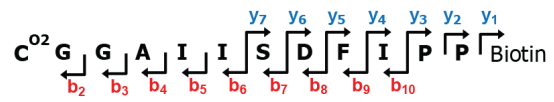

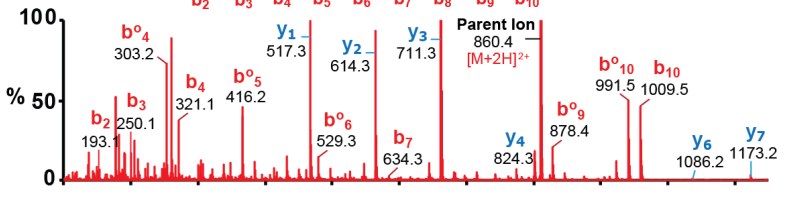

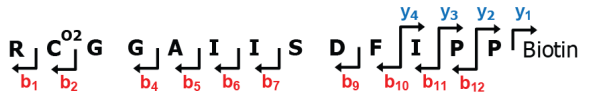

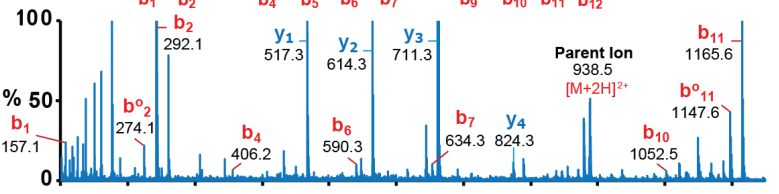

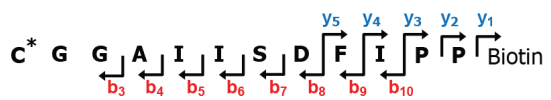

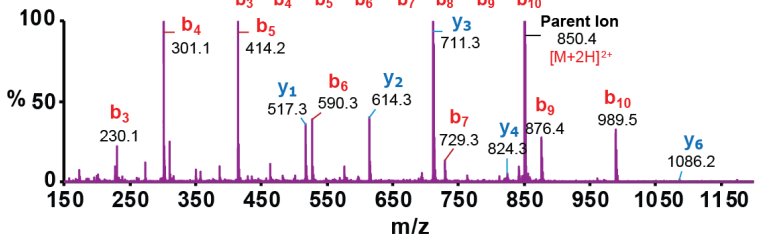

Figure 4. PCO-Catalyzed Cys-sulfinic acid formation renders RAP2 2 -13 a substrate for

732 ATE1 catalyzed arginylation. (a) ${ }^{14} \mathrm{C}$-Arg incorporation by ATE1 into the 12-mer Nterminal RAP2 peptide ( $\mathrm{H}_{2} \mathrm{~N}$-XGGAIISDFIPP(PEG)K(biotin)- $\mathrm{NH}_{2}, \mathrm{X}=\mathrm{Gly}$, Asp, Cys or

734 Cys-sulfonic acid $\left.\left(\mathrm{C}_{(\mathrm{O}}\right)\right)$ ), was assayed by liquid scintillation counting of immobilized biotinylated peptides after the arginylation reaction and removal of unreacted ${ }^{14} \mathrm{C}-\operatorname{Arg}(\mathrm{n}=3)$. In the case of the Cys-starting peptide (RAP2 $2-13$ ), ATE1 activity was strongly dependent on the presence of PCO1 or PCO4. (b) Scheme showing PCO- and ATE1-catalyzed reactions on 
bioRxiv preprint doi: https://doi.org/10.1101/069336; this version posted December 9, 2016. The copyright holder for this preprint (which

was not certified by peer review) is the author/funder, who has granted bioRxiv a license to display the preprint in perpetuity. It is made available under aCC-BY-NC 4.0 International license.

White $M$ et al.

738

739

740

741

742

743

744

745

746

747

Nt-Cys RAP2.2, as validated in this study. (c) LC-MS spectra of products of equivalent assays with Cys-initiated RAP2 2 -13 using non-radiolabelled Arg, revealing a sequential mass increase of +32 (corresponding to oxidation) and $+156 \mathrm{Da}$ (corresponding to arginylation) only in the presence of PCO and ATE1 (blue spectrum). The red spectrum shows a $+32 \mathrm{Da}$ mass increase for Cys-RAP2 $2-13$ incubated $+\mathrm{PCO} /-\mathrm{ATE}$, demonstrating Cys-sulfonic acid formation as expected. Purple spectra show +12 Da products formed upon incubation of CysRAP $2_{2-13}$ in the absence of PCO +/-ATE (for explanation of this mass increase see text and Supplementary Figure 6); the black spectrum shows Cys-RAP2 $2-13$ dissolved in $\mathrm{H}_{2} \mathrm{O}$.

b- and y-ion series spectra generated by MS/MS analysis of Cys-RAP2 2 -13 only (no incubation; black), Cys-RAP2 $2-13$ incubated +PCO/-ATE (red), Cys-RAP2 2 -13 incubated with PCO and ATE1 (blue) and Cys-RAP2 2-13 incubated without PCO or ATE1 (purple), confirming arginylation only at the N-terminus of PCO-modified RAP2 2-13. 